\title{
Corporate Social Responsibility (CSR) and Sustainability in Asian Luxury Hotels: Policies, Practices and Standards
}

\author{
Vimolboon Cherapanukorn ${ }^{1,2} \&$ Kirsten Focken ${ }^{2}$ \\ ${ }^{1}$ Collage of Art, Media and Technology, Chiang Mai Universty, Thailand \\ ${ }^{2}$ School of Hotel and Tourism Management, Hong Kong Polytechnic University, Hong Kong \\ Correspondence: Vimolboon Cherapanukorn, Collage of Art, Media and Technology, Chiang Mai University, \\ Thailand. E-mail: vimolboon19@gmail.com
}

\author{
Received: January 22, 2014 Accepted: February 27, 2014 Online Published: March 26, 2014 \\ doi:10.5539/ass.v10n8p198 URL: http://dx.doi.org/10.5539/ass.v10n8p198
}

\begin{abstract}
The tourism and hospitality industry claims to embrace the concept of corporate social responsibility (CSR) but it seems unclear how and if companies integrate CSR activities into the core business and how they demonstrate real impacts and positive changes. The purpose of this research is to understand how Asian luxury hotels communicate about their CSR policies, practices and standards. It gives insights of best practices of CSR from luxury hotel groups that operate predominantly in Asia. The findings reveal that CSR is a blurry subject and there is a lack of an overall accepted definition and guidelines. The reporting of CSR activities by the Asian luxury hotels includes various overall activities, many of which are normal business practices. Many of these hotel groups are adopting international standards and most of them underline the importance of the environment and society. The study concludes that the motivation for CSR is oriented towards sustaining the basis for their operations. The outcome of the research suggests that further studies should analyze different hotel segments, such as local hotels or small-medium size hotels, in one particular country or comparing between various countries.
\end{abstract}

Keywords: sustainability, CSR strategy, Asia, hotels

\section{Introduction}

Sustainable development and responsible business practices are increasingly important in all business sectors. The tourism and hospitality industries have the potential to both contribute to a degradation of natural and cultural assets as well as to an unequal distribution of benefits and wealth. The potential positive contribution of tourism consists of the conservation and protection of the nature as tourism depends on the natural assets and businesses are largely dependent on sustainable management practices. However, there are many tourism developments that harm natural or cultural assets and are managed in an unsustainable and unequal way. Furthermore, in recent years global tourism is more closely linked to climate change. Tourism involves the movement of people from their homes to other destinations and accounts for about $50 \%$ of traffic movements (Simpson, Gössling, Scott, Hall, \& Gladin, 2008).

There is no easy solution how to reduce the negative effects and it seems contradictory to the idea of tourism contributing to conservation and poverty reduction. However, there is a variety of reports and initiatives that try to reduce the carbon footprint of the tourism industry and some destinations are aiming to become carbon neutral (Bohdanowisz \& Zientara, 2008; Forsyth et al., 2008; Insch, 2009). It can be stated that climate change related to pressing environmental issues and constraints make governments and industry stakeholder more aware of the necessity to change and many organizations are now defining green growth principles, practices and programs (Lipman, DeLacy, Voster, Hawkins, \& Jiang, 2012). The various authors in this publication, leaders from the tourism and hospitality industry, claim and demonstrate that the hospitality industry is embracing the concept of corporate social responsibility or CSR (Sheldon \& Park, 2011). However, they stress that many issues are not solved and that governments and private businesses across the world have to improve cooperation. Thus, there is no doubt that many professionals and executives in the hospitably industries have ethical standards and believe their companies should contribute to a more sustainable development.

On the other hand, it is widely claimed that companies engage in CSR for purely economic reasons, mainly to 
improve the image of the company. Some studies suggest that it is time for the hospitality industry to be proactive and live up to the expectations to be hospitable and to care for surrounding world (Holcomb, Upchurch, \& Okumus, 2007; Sheldon \& Park, 2011). According to the previous studies, there is a prevailing awareness of the necessity and benefits; however it seems to be unclear how to integrate the activities into the core business and how to demonstrate real impacts and positive changes.

Asia, as a tourist destination, has the largest increasing number of tourist arrival compared with other regions in 2011 (World Tourism Organization, 2012). Therefore, the hospitality and tourism industry has become one of the most important industries in this region. In particular, the Pacific Asia Tourism Association (2013) or PATA, noted that the luxury hotel industry has experienced high growth over the past 10-20 years in Asia. Especially, these hospitality industries have been expanding in the most of Asian countries and experienced the highest growth rates in terms of revenues and profits (Nasdaq, 2013). The growth is fuelled by raising intraregional travel, in particular by Chinese tourists.

Many of these luxury hotels are operated in major cities, historic townships and tourists' attraction locations, such as mountain, lakeside or beach, attracting greater numbers of travellers and thereby imposing an increasing ecological and social responsible footprint (Chung \& Parker, 2010). These authors claim that the hospitality industry's social and environmental impacts have not received the same levels of attention in Asia, comparing with mining, chemical and manufacturing industries, but this scenario seems to be changing.

This study examine what role sustainability plays in this rapidly growing market of Asian luxury hotels and if the hotel groups in this region and market segment implement and report CSR practices such as can be observed in other regions. Most of hotels are following global standards and complying with guidelines established by the World Travel and Tourism Council (WTTC) and the United Nation World Tourism Organization (UNWTO). For a global adaption of sustainable business practices, it is important to understand how CSR practices are currently adapted in various segments of the industry and geographical areas. However, there seems to be limited research with regard to CSR, focusing on special hotel segments and also there is limited research about the Asian hotel market. This research is therefore proposed to understand how luxury hotels in Asia report and communicate about their CSR policies, practices and what standards they follow. It also aims to give some insights and best practices of CSR from a specific travel segment: luxury hotels that operate predominantly in Asia.

In summary, the research study purposes to answer the following questions: What are the top Asian luxury hotel brands communicating with regard to CSR policies and practices and what standards do they apply? How does their approach align with global CSR and sustainable tourism practices in the hospitality industry?

The study contributes to a better understanding of CSR activities and approaches in the hospitality industry. By describing best practices and comparing international studies and reports, it will give input and recommendations to the hotel industry how to best approach the CSR subject and what the opportunities and barriers for sustainable businesses are.

\section{Literature Review}

\subsection{CSR Overview and Motivations}

There are manifold definitions of CSR in academic and other publications. The World Business Council for Sustainable Development (2010) or WBCSD defines Corporate Social Responsibility as the continuing commitment by business to behave ethically and contribute to economic development while improving the quality of life of the workforce and their families as well as the local community and society at large. This definition includes the notion of the "triple bottom line" explained by the famous publication of the study by Elkington in 1997. According to this concept a business is sustainable when it lives up to the "triple bottom line" of economic prosperity, environmental quality and social justice. This idea therefore stresses three main aspects of CSR activities; economic, environmental, and social. The same idea is reflected by the definition of the European Commission (2011) stating that CSR is a concept whereby companies integrate social, environmental, and ethical and human rights' concerns into their business operations and core strategy in close collaboration with their stakeholders. Thus, the other main elements of CSR are the stakeholders, such as workforce, communities and the society, or as the Economist (2008) explained that CSR is about the attitude that firms adopt towards their stakeholders: customers, employees and the broader society.

One of the main shortcomings with regard to sustainability and CSR is a lack of clear conceptualization and related to this a lack of monitoring and measurement. According to the Economist (2008), many companies found it hard to measure an implementation of sustainable business, corporate citizenship and CSR because it is a wide-ranging and fuzzy subject. Also, studies in the tourism sector reveal that managers do not totally 
understand CSR (Sheldon \& Park, 2011).

A business-oriented approach of CSR by Kotler and Lee in 2005, noted that CSR is a commitment to improve community well-being through discretionary business practices and contributions of corporate resources. In another important publication Porter and Kramer (2006) explained that CSR should be integrating business and society because corporations need a healthy society; includes productive workforce through education, health care, equal opportunities; efficient utilization of land, water and energy and good governance.

There are many factors that encourage the industry to adopt the concept of CSR (Argandoña \& Hoivik, 2009). Moreover, Friedman (1970) points out that the business responsibility is to conduct the business in accordance with their desires and it will be aimed to make as much profit as possible. However, from the profit-seeking perspective of the organizations, investments in the benefits of socially responsible activities are also important. The financial performance is noticed as one of the intentions that persuade many tourism and hospitality companies to practice CSR. There are many significant studies that investigate the relationship between CSR and business's corporate final performance (CFP) (Inoue \& Park, 2011). As mentioned by Lee and Park (2009) CSR investment can improve both short-term and long-term financial performance of companies. There is also supported by Inoue and Park (2011) that CSR activities could increase tourism-related companies' profitability. Moreover, many scholars point out that CSR could be regarded in order to maximize stakeholders' wealth, not only to pursue the business's interest. Other studies claim that CSR provides positive effects to the organizations' performance aspects, such as the employees' satisfaction (Peterson, 2004; Chiang, 2010), customers' satisfaction (Senthikumar, Ananth, \& Arulraj, 2011; Luo \& Bhattachara, 2006) and company's reputation (Brammer \& Millington, 2005; Janney \& Gove, 2011).

Therefore, it can be seen that there is evident from the literature that CSR is a divers theme with various definitions and motivations for firms, including tourism and hospitality organizations, in order to include CSR in their communication, strategy or even operations management.

\subsection{CSR in Asia}

Corporate social responsibility has been created and developed differently across the world and it reflects the relationship between the society and business. Some scholars stress that CSR is largely a western phenomenon (Chamber, Chapple, Moon, \& Sullivan, 2003). They explain that CSR is a function of economic wealth and most European countries, in general, have been associated with higher levels of economic wealth than Asian countries. However, Welford (2005) states that it should not be assumed that Asian countries are less developed in CSR than Western countries, which includes countries from European and North American regions. The study by Baughn, Bodie and McIntosh in 2007, focusing on 15 Asian countries, demonstrates that Japanese companies are noteworthy for their CSR performance and the research by Tanimoto and Suzuki in 2005 mentions that this country also shows the highest number of companies using GRI (Global Reporting Initiative).

There is further evidence from the literature that the concept of CSR requires companies to consider many significant local factors, such as standards established by laws and mandatory regulation, social expectations/demands and the governments' policies (Williams \& Aguilera, 2007). These factors depend largely on national regulations. Furthermore, the research by Cramer (2006) explains that organizations need to pay attention to the specific social needs and problems that exist in the country. Therefore, the specific political and socio-cultural context of the country affects the meaning and consideration of CSR (Cramer, 2006). Other studies mainly focus on the views of employees in the tourism and hospitality industry in various countries (Albdour \& Altarawneh, 2012; Huimin \& Ryan, 2011). They show that different cultural backgrounds of the employees may induce their perceptions towards the concept and practices of CSR. This includes the local's spiritual, religious dimensions, beliefs, value and rituals (White, 2008).

Since the 1990s, Asian business leaders have turned their attention to adapting the concept of sustainability and social responsibility into their organization (Cramer \& Prepscius, 2008). They claim that most of the CSR practices of companies are integrated with the environment, society and governance factors where the organization operates. According to this study sustainability is a global concept, while CSR has developed differently in different parts of the world. For this reason international standards are created by the International Organization for Standardization or ISO (2013) to scope and develop a guidance on social responsibility and environment, such as ISO 26000 (Social responsibility), ISO 14000 (Environmental management) and ISO 50001 (Energy management). In Asia, an increasing number of organizations follow and adopt the ISO standards (Cramer \& Prepscius, 2007). Another study confirms this and explains that corporate involvement and attention by Asian companies is growing. According to the research of Chung \& Parker (2010), over 700 Singapore companies are ISO 14001 certified, which significantly increased from 369 companies in 2002. 
A study by Welford (2011) presents the main CSR issues in Asia from 2009 to 2011 and explains that the popularity of CSR success is based on the engagement of all stakeholder partnerships and follows global standards. He reports in his study that climate change, water issues, supply chains relation, community development, biodiversity, health issues, human resources, customer satisfactions and sustainable consumption are the hot CSR issues in Asia for the next ten years. Another study about CSR in Asia states that the escalating awareness of CSR in Asian businesses is due not to changing expectations and values of employees, but rather due to the Asian economic crisis (Tsai, Tsang, \& Cheng, 2012). They explain that a repeatedly mentioned cause of the crisis is the lack of transparency of business operations in Asia.

It can be concluded from the literature that CSR clearly has a global significance. It is an important aspect in the hospitality and tourism industry and many companies are engaged in developing and implementing CSR strategies and practices. Research also points out that there are significant differences and that there may be a connection to cultural and regional conditions. Many previous studies described CSR in the Asian context (Chamber et al., 2003; Cramer \& Prepscius, 2008), however, there is limited research that focuses on Asia hotel companies and their CSR practices.

\subsection{CSR in Tourism and Hospitality}

In recent decades, CSR has been carried out in tourism-related industries as a form of sustainability. Ensuring high labor standards, promoting environmental sustainability and supporting local communities are important aspects of global hotel groups (Bohdanowisz \& Zientara, 2008). Many research studies show that hotel firms are actively promoting CSR activities and state that CSR initiatives in the tourism and hospitality sector are becoming more significant, in line with other business sectors (Holcomb et al., 2007). They found out that many leading international hotel firms adopt the integration of social and environmental objectives into their operations and use this as a basis for developing unique competitive advantages, such as Hilton, Intercontinental and Marriott. Other global hotel best practices in the hotel industries are the European groups Scandic and Rezidor (Bohdanowisz \& Zientara, 2008; Hsieh, 2012). However, it is also repeatedly stated that there is less focus on CSR issues than in other industries (Hsieh, 2012) or that hotels are rather complacent with the implementation of CSR (Levy \& Park, 2011).

Research about CSR in the hospitality industry has focused on various markets and identified the main issues and drivers for activities as presented in Table 1 .

Table 1. Literature overview CSR practices reported in the hospitality industry

\begin{tabular}{|c|c|c|c|c|}
\hline Author & Research Target & Outcomes: Main Issues/Drivers & Best Practice & Standards/Verification \\
\hline $\begin{array}{l}\text { Holcomb et al. } \\
\text { (2007) }\end{array}$ & $\begin{array}{l}\text { Top Ten Hotel } \\
\text { Groups }\end{array}$ & $\begin{array}{lr}\text { Communities } & \text { Workforce } \\
\text { (Diversity), Less reported: } \\
\text { Vision + values, environment }\end{array}$ & $\begin{array}{l}\text { Hilton, } \\
\text { Marriott }\end{array}$ & $\begin{array}{l}\text { CSR audit (Hilton) UN } \\
\text { Global Compact } \\
\text { principles (Accor) }\end{array}$ \\
\hline $\begin{array}{l}\text { Bohdanowisz } \\
\& \quad \text { Zientara } \\
\text { (2008) }\end{array}$ & $\begin{array}{l}13 \text { global hotel } \\
\text { brands }\end{array}$ & $\begin{array}{l}\text { Donations to charities, local } \\
\text { communication, purchase of } \\
\text { fair-trade goods }\end{array}$ & $\begin{array}{l}\text { Scandic-CSR } \\
\text { influences } \\
\text { decisions }\end{array}$ & $\mathrm{n} / \mathrm{a}$ \\
\hline $\begin{array}{l}\text { Chung \& } \\
\text { Parket (2010) }\end{array}$ & $\begin{array}{l}\text { Singapore } \\
\text { hospitality } \\
\text { industry }\end{array}$ & $\begin{array}{l}\text { Employing local people, } \\
\text { consuming energy, water, food, } \\
\text { paper, pollution }\end{array}$ & $\mathrm{n} / \mathrm{a}$ & $\begin{array}{l}\text { Triple Bottom Line (only } \\
\text { framework) }\end{array}$ \\
\hline $\begin{array}{l}\text { Levy \& Park } \\
(2011)\end{array}$ & $\begin{array}{l}\text { US lodging } \\
\text { industry ( } 41 \mathrm{GM} \\
\text { of hotels) }\end{array}$ & $\begin{array}{l}\text { Priority are cost saving through } \\
\text { energy, water, and waste } \\
\text { management }\end{array}$ & $\mathrm{n} / \mathrm{a}$ & $\mathrm{n} / \mathrm{a}$ \\
\hline $\begin{array}{l}\text { Sheldon \& park } \\
\text { (2011) }\end{array}$ & $\begin{array}{l}50 \text { global hotel } \\
\text { groups }\end{array}$ & $\begin{array}{l}46 \% \text { report environmental } \\
\text { initiatives: energy management } \\
\text { and environmental education } \\
\text { most frequent }\end{array}$ & $\begin{array}{l}\text { Wyndham, IHG, } \\
\text { Accor, Whitbread, } \\
\text { Hyattm, Rezidor }\end{array}$ & $\begin{array}{l}\text { Mostly internal audits, } 13 \\
\text { companies show awards } \\
\text { United Nations' Global }\end{array}$ \\
\hline Hsieh (2012) & $\begin{array}{l}50 \text { global hotel } \\
\text { groups }\end{array}$ & $\begin{array}{l}46 \% \text { report environmental } \\
\text { initiatives: energy management } \\
\text { and environmental education } \\
\text { most frequent }\end{array}$ & $\begin{array}{l}\text { Wyndham, IHG } \\
\text { Accor, Whitbread, } \\
\text { Hyatt, Rezidor, Sol } \\
\text { Melia, TUI Scandic }\end{array}$ & $\begin{array}{l}\text { Mostly internal audits, } 13 \\
\text { companies show awards, } \\
\text { United Nations' Global } \\
\text { Compact most relevant }\end{array}$ \\
\hline $\begin{array}{l}\text { Tsai et } \\
(2012)\end{array}$ & $\begin{array}{l}\text { Hotel } \\
\text { employees' } \\
\text { perceptions on } \\
\text { CSR in Hong } \\
\text { Kong }\end{array}$ & $\begin{array}{l}\text { Low awareness and importance } \\
\text { of environmental issues and } \\
\text { community but showing } \\
\text { commitments very important }\end{array}$ & $\mathrm{n} / \mathrm{a}$ & $\mathrm{n} / \mathrm{a}$ \\
\hline
\end{tabular}


From table 1, four major categories of CSR activities can be defined; community, employees, supply chain and environment.

Many studies focus on people issues and relate community activities with employee focused activities and also activities related to other stakeholders. Bohdanowisz and Zientara (2008) report that CSR initiatives in the hospitality industry have a high impact on the host community's socioeconomic situation. According to the study of main global hotel brands, the main CSR activities are donations to charity, working with local communities and purchasing fair-trade goods. However, the study concludes that initiatives requiring personal involvement on the part of hotel employees are more likely to result in longer term benefits. A similar perspective is given by Franklin (2008) who states that CSR is about the attitude that firms adopt towards their stakeholders: customers, employees and the broader society.

The study about corporate social responsibility in the hospitality industry in Singapore by Chung and Parker (2010) also centers on CSR activities related to people and stakeholder. They point out the following main CSR issues: employing local people, consuming less energy, water, food, paper and pollution and thereby reducing the negative impact on local communities. This study stresses the significance of relationships with local business and government in the country where the business operates. The authors further describe that some international hotel chains develop stand-alone pronouncement about the social implementing and environmental initiatives, while many other companies create partnerships or CSR alliances.

Another study identifies similar drivers for the adoption of CSR practices; philosophical and ethical issues as well as community related issues (Sheldon \& Park 2011). The study explores the topic in the US travel industry by sending surveys to 231 tourism companies asking for CSR activities, perceptions, drivers, inhibitors and challenges. The most important actions reported are related to the conservation and preservation of the natural environment and the promotion of ecotourism and responsible travel. The study further reveals that CSR is an important subject in the US travel industry however implementation is lacking behind. The reasons given why CSR implementation is not at the state as it should be limited resources and understanding. Additionally, the authors conclude that the travel industry expects the government to take leadership by implementing standards and certifications or identifying champions and networks.

Other studies of CSR adoption in the hospitality and tourism industries confirm that sustainability and environmental issues are the similar focus areas. Levy and Park (2011) conducted a study in the US hotel industry asking various hotels for their CSR activities and the benefits. $25 \%$ of the respondents were luxury hotels and more than $50 \%$ mid- and upscale. This is a clear indication that this segment is more concerned with CSR. The outcome of this study illustrates that most hotels focus on environmental practices in order to achieve cost savings.

Hsieh (2012) demonstrates that $46 \%$ of the top 50 global hotel groups report initiatives related to the environmental issues. The author states that the large companies report more often and conclude that they are more likely to see competitive advantage in making environmental improvements. However relatively few hotel groups report environmental policies that reflect a real top management commitment. Another interesting finding of this study is that $69 \%$ of the hotels that report environmental initiatives are based in Europe, $37 \%$ in North America-based and 33\% in Asia.

Apart from the community support and environmental conservation, hotel companies also consider relationships with their stakeholder groups, such as employees, suppliers, investors and customers. With regard to employee-related CSR practices most activities of the leading hotels are related to workforce diversity, equitable benefits and career advancement (Holcomb et al., 2007). Another study of Hong Kong hotels' CSR (Tsai et al., 2012) was made from the employee's perspective. The outcome shows that the employees consider activities neither preserving environment nor supporting communities as relevant and important. This result may show a general appreciation of CSR for PR reasons but a low sense for its implementation in Hong Kong.

There are numerous hospitality certification programs and associated measurement systems that provide sustainability criteria for hotels to evaluate and benchmark performance while gaining industry wide recognition for their efforts (Levy \& Park, 2011). Some of these certificates are named in various studies but there is no research and analysis of the adoption of these in the hospitality industries. It seems that many international hotel companies are committed to follow a food safety system and achieve the food safety certification from the world-wide institution, which is known as the Hazard Analysis and Critical Control Point system (HACCP), to verify and guarantee the quality of the hotel.

Within Asia, Singapore developed the "ASEAN Green Hotel Awards" which is initiated by the ASEAN member counties (Chung \& Parker, 2010). This award is based upon eleven criteria for assessing environmental and 
energy conservation strategies including environmental policy and actions for hotel operations, waste management, energy efficiency, water efficiency, and air quality management.

In summary there is numerous research about CSR in the hospitality industry and the focal areas hotels are engaging. It can be seen that communities and environment issues are the two top priorities with regard to CSR performance. However the criteria used to assess the adoption of CSR are very different and a comparison between the studies is difficult. CSR in general and in the hospitality industry is a well-reported and researched subject but there is an apparent lack of accepted concepts and frameworks.

\section{Method}

This study examines the web sites of the 10 Asian international hotel companies listed as 'the most sustainably successful hospitality brands' in the brand survey that was conducted by the Brand Company (2012). According to this report the ten leading hotel companies were chosen based on five key drivers of brand success: design \& communications, brand name, people, place, products and services.

The list of top 10 successful Asian Luxury hotel brands by the brand Company (2012) included Shangri-La Hotels \& Resorts, The Peninsula Hotels, Mandarin Oriental Hotels, Banyan Tree Hotels \& resorts, Raffles Hotels \& Resorts, Aman Resorts, Six Sense Resorts \& spas The Langham Hotels, Langham Place Hotels and Marco Polo Hotels. However, it is noted that Langham Hotels and Langham Place Hotels are under the same operated hotel group which is the Langham hotel group. Thus, the researchers grouped the Langham Hotels and Langham Place Hotels together and added one more additional Asian hotel group: 'DusitThani' into the research samples of this study. All 10 Asian hotel groups are on the list of the 30 brands assessed and seem a good addition in terms of diversifying the sample with dominance of Hong Kong, Bangkok and Singapore based groups. The list of 10 potential sample Asian hotels companies through the Table 2.

Table 2. 10 Leading Asian hotel brands

\begin{tabular}{ll}
\hline & Hotels list \\
\hline 1 & Shangri-La Hotels \& Resorts \\
2 & The Peninsula Hotels \\
3 & Mandarin Oriental Hotels \\
4 & Banyan Tree Hotels \& Resorts \\
5 & Raffles Hotels \& Resorts \\
6 & Aman Resorts \\
7 & Six Senses Resorts \& Spas \\
8 & The Langham /Langham Place \\
9 & Marco Polo Hotels \\
10 & DusitThani \\
\hline
\end{tabular}

Source from: the Brand Company (2012)

The study employs a qualitative research approach by adopting the content analysis to review the online content of the sample hotel companies, specifically the text related to their CSR and sustainability policies and practices.

Content analysis technique is applied in this study. As Hsieh (2012) that it is is a technique that facilitates the systematic and objective identification and categorization of communication themes or characteristics. Categories were identified through this technique (Weber, 1985). The analysis of the context was conducted by identifying coding criteria, and then quantified and tallied their presence in the chosen texts by following the keywords as a coding protocol. All keywords were analysed and adapted from the scope and explanation regard to environmental and social responsibility by the International Standardize Organization (2013). Furthermore, the data was collected from the online platform, which covered the CSR information available through the company's annual and/or sustainability or social corporate reports and company's website as the primary source. In addition online news and reports that related to CSR of the selected hotel companies were included as secondary information sources.

In order to analysis standards and to develop a guide for corporate social responsibility practices, the researchers used several environmental management and social responsibility standards such as ISO 14001, ISO26000, the Global Reporting Initiative (GRI); the Earth Check institution and the ICC Business Charter for Sustainable 
Development. Of all these standards, ISO 14001 and ISO26000 are the most international standard and covered the area of CSR practices based on the explanation by the international standardize organization (2013). ISO14001 is the most widely used environmental management system, with more than 188,815 organizations certified in 155 countries, while ISO26000 provides guidance to help companies clarify what social responsibility is, helps businesses and organizations translate principles into effective actions and shares best practices relating to social responsibility, globally. Therefore, this study used the ISO 14001 and ISO26000 as a main framework for the coding indicators in assessing the CSR policies and efforts of the sampled hotel companies.

For the evaluation of the areas of CSR practice and activities by the top Asian hotel companies a detailed literature review regarding CSR in hospitality and best practices are identified (Table 3) and the main criteria were identified on this basis. Subsequently the criteria were divided into four main CSR actions and practices: community, environment, employees and supply chain. The environmental components include; energy efficiency, water conservation, waste management, bio-diversity conservations, and environmental construction. The Community components cover: education (scholarship, training, mentoring, and facility supporting actions), local welfare, donation and fundraising and health care. The employee components include: career opportunity, recruitment, communication, training and career rewards and benefits. The supply chain components cover: companies' suppliers, customer/guests and investors (include all shareholders of the company).

Table 3. Keywords

\begin{tabular}{|c|c|c|c|c|c|c|}
\hline Policy & Community & Environment & Employees & Supply Chain & Standards & Awards \\
\hline Purpose & Healthcare & Recycle & $\begin{array}{l}\text { Performance } \\
\text { Management }\end{array}$ & Relationship with guests & $\begin{array}{l}\text { ISO } \\
14001^{\mathrm{a}}\end{array}$ & $\begin{array}{l}\text { the Asian } \\
\text { CSR } \\
\text { Awards } \\
\text { Program }\end{array}$ \\
\hline $\begin{array}{l}\text { Vision } \\
\text { Mission }\end{array}$ & Grants Donation in kind & $\begin{array}{l}\text { Pollution } \\
\text { control }\end{array}$ & $\begin{array}{l}\text { Compensation \& } \\
\text { Rewards }\end{array}$ & $\begin{array}{l}\text { Relationship } \\
\text { suppliers }\end{array}$ & $\mathrm{ISO} 26000^{\mathrm{b}}$ & $\begin{array}{l}\text { Earth } \\
\text { Check } \\
\text { Certificate }\end{array}$ \\
\hline Enduring values & Education & $\begin{array}{l}\text { Waste } \\
\text { management }\end{array}$ & Advancement & $\begin{array}{l}\text { Relationship } \\
\text { shareholders }\end{array}$ & $\begin{array}{l}\text { OHSA } \\
18001^{\mathrm{c}}\end{array}$ & $\begin{array}{l}\text { Global } \\
\text { CSR } \\
\text { Award }\end{array}$ \\
\hline Accountability & Scholarship/internship & $\begin{array}{l}\text { Water } \\
\text { conservation }\end{array}$ & $\begin{array}{l}\text { Diversity/equal } \\
\text { opportunity }\end{array}$ & Strong in partnerships & & HCCAP $^{d}$ \\
\hline \multirow[t]{4}{*}{ Commitment } & Corporate giving & $\begin{array}{l}\text { Energy } \\
\text { management }\end{array}$ & $\begin{array}{l}\text { Employee } \\
\text { assistance \& } \\
\text { communication }\end{array}$ & $\begin{array}{l}\text { Clear/honest/respectful } \\
\text { to all stakeholders }\end{array}$ & & \\
\hline & Volunteerism & $\begin{array}{l}\text { Restore } \\
\text { nature } \\
\text { habitats }\end{array}$ & Recruitment & & & \\
\hline & $\begin{array}{l}\text { Local/nation/world } \\
\text { Welfare }\end{array}$ & $\begin{array}{l}\text { Biodiversity } \\
\text { conservation }\end{array}$ & $\begin{array}{l}\text { Training and } \\
\text { development }\end{array}$ & & & \\
\hline & & & $\begin{array}{l}\text { Fair \& Equitable } \\
\text { benefits }\end{array}$ & & & \\
\hline
\end{tabular}

\footnotetext{
${ }^{a}$ The International Organization for Standardization focuses on environmental management

${ }^{\mathrm{b}}$ The International Organization for Standardization focuses on social responsibility

${ }^{\mathrm{c}}$ The Occupational Health \& Safety Management Systems focus on working conditions and environments for all employees

${ }^{\mathrm{d}}$ The Hazard Analysis and Critical Control Point system
}

\section{Research Findings}

The 10 selected international Asian hotel groups posses hotel properties around the world between $10-100$ (excluding future opening properties). These groups are based in Asia and have properties in other parts of the world, in particular in the US, Europe and Middle East (Table 4). In this study, the researchers followed the six regions as categorized by the World Tourism Organization or UNWTO (n. d.) in order to group the location where the hotel properties' operate. It is noted here that these six regions cover Americas, Europe, Africa, East 
Asia and Pacific, Middle East and south Asia. Hotel groups with Asian origin and headquarter seem to have main growth and expansion plans directed to destinations throughout Asia and the Middle East. This is relevant for the research objective to get evidence of the current state and potential outlook of CSR in the Asian hospitality industry.

From the content analyzing, the coding taxonomy through the hotel companies' website of the 10 Asia hotel brands (Appendix 1) illustrates that most of hotel groups are reporting about their CSR activities in a rather detailed way, except Aman Resorts. This hotel group has a very unique offering with small luxury hotels situated in outstanding locations. The CSR policies and communication seem to follow the overall slogan 'less is more'. Although there is no evidence for CSR activities various articles and links to tour companies explain that the group is deeply dedicated to sustainable development (Poon, 2011).

Table 4. The number of hotels' property and the headquarter office's location

\begin{tabular}{|c|c|c|c|}
\hline Hotels & $\begin{array}{l}\text { Total No. hotels' } \\
\text { property }\end{array}$ & Hotels' property by region & $\begin{array}{l}\text { Location of Head } \\
\text { office }\end{array}$ \\
\hline $\begin{array}{l}\text { Shangri-La Hotels \& } \\
\text { Resorts }\end{array}$ & 118 & $\begin{array}{l}\text { East Asia-Pacific (89), South Asia (7), Middle East (6), } \\
\text { Americas (2), Europe (4), Africa (1) }\end{array}$ & Hong Kong \\
\hline The Peninsula Hotels & 9 & East Asia-Pacific (6), Americas (3) & $\begin{array}{l}\text { Hong } \\
\text { Kong/Shanghai }\end{array}$ \\
\hline $\begin{array}{l}\text { Mandarin Oriental } \\
\text { Hotels }\end{array}$ & 28 & East Asia-Pacific (14), Americas (8), Europe (6) & Hong Kong \\
\hline $\begin{array}{l}\text { Banyan Tree Hotels \& } \\
\text { Resorts }\end{array}$ & 26 & $\begin{array}{l}\text { East Asia-Pacific (17), South Asia (3), Middle East (3), } \\
\text { Americas (2), Africa (1) }\end{array}$ & Singapore \\
\hline $\begin{array}{l}\text { Raffles Hotels \& } \\
\text { Resorts }\end{array}$ & 10 & $\begin{array}{l}\text { East Asia-Pacific (6), Middle East (2), Europe (1), } \\
\text { Africa (1) }\end{array}$ & Singapore \\
\hline Aman Resorts & 27 & $\begin{array}{l}\text { East Asia-Pacific (15), South Asia (5), Americas (4), } \\
\text { Europe (6), Africa (1) }\end{array}$ & Singapore \\
\hline $\begin{array}{l}\text { Six Senses Resorts \& } \\
\text { Spas }\end{array}$ & 9 & East Asia-Pacific (6), South Asia (1), Middle East (2) & Thailand \\
\hline $\begin{array}{l}\text { The Langham } \\
\text { /Langham Place }\end{array}$ & 21 & $\begin{array}{l}\text { East Asia-Pacific (15), South Asia (1), Americas (4), } \\
\text { Europe (1) }\end{array}$ & Hong Kong \\
\hline Marco Polo Hotels & 15 & East Asia-Pacific (15) & Hong Kong \\
\hline DusitThani & 18 & East Asia-Pacific (13), South Asia (1), Middle East (4) & Thailand \\
\hline
\end{tabular}

The CSR reporting of the other selected hotels is driven by the Head Office. Only three groups report separately their activities for each hotel (Banyan Tree, Shangri La, and Six Senses). The information on the websites is generally rather difficult to find under 'about us' which is usually a small link on the bottom of the homepage. It is questionable if potential customers are taking the effort to find it and therefore the marketing effect is not evident. The exception is Banyan Tree who has a special dedicated website called 'Banyan Tree Global Foundation' (2008) that reports about CSR activities. The rather hidden communication in general is in contradiction to the vision and policies of most hotels that include catchy slogans in order to state their values and their care for the world (e.g. embrace, connect, greening communities and reach).

From the research finding, it can be stated that two of the selected hotel chains use CSR as a competitive advantage, Banyan Tree and Six Senses. They position sustainable practices as a core of the operations and many of the activities mentioned on websites and in other press articles affirm the statements of the groups such as "Agent of social and economic development through responsible tourism" (Banyan Tree) and "Responsible and caring attitude is intrinsic to the brand" (Six Senses). These two groups are integrating business and society as suggested by Porter and Kramer (2006) and it could be assumed that they are conscious of the fact that they rely on the environment, employees and communities for their business. The building of these successful sustainable luxury hotel brands is centered on sustainable practices with low negative impact and the CSR activities evidently support business goals, related to core products and markets as Kotler and Lee (2005) proposed in their study.

Regarding the four categories of CSR activities, there is a preponderance of activities related to the community and the environment which confirms the studies from other parts of the world. The activities as charity, donations and fund raising still seem to be a main part of CSR activities for hotels globally. With regard to the 
environment the activities are all focused on energy, water and waste management. Some hotels state that costs savings are achieved in line with the study of Levy and Park (2011) that identified cost savings as a priority for CSR activities of US hotels. Apart of these environmental activities many hotels have programs to protect the biodiversity and in particular marine conservation (Shangri La, Six Senses, Banyan Tree and DusitThani). Banyan Tree even developed two marine special labs for research and provides basic facilities and equipment for important fieldwork conducted by visiting expert scientists from around the world. The necessity is obvious as many of these groups have hotels that rely on the sea experience for customers such as beach, diving or other water sports.

The reported CSR activities related to employees and the workforce are mainly concerned with diversity, anti-harassment and equal opportunities. However, many hotels claim activities in this area that should not be regarded as CSR activities. According to the definition CSR activities are discretionary (Kotler \& Lee, 2005) and therefore employee training, recruitment and compensation are core activities of any organization rather than CSR activities. Similarly, there is a multitude of general approaches that sound good for employees, such as open-door policy, career planning or executive development programs that should not be part of the CSR program. Employee relations are closely related to other stakeholder relations summarized in this study under 'supply chain'. The selected hotels report various other activities mostly related to sourcing locally. There are also several activities that are not CSR according to the definition, in particular related to clients. Providing experiences for clients and membership programs for guests are clearly directing towards finding and maintaining clients. In the same logic meeting shareholder expectations in terms of financial returns should certainly not fall under CSR activities.

All of the analyses leading Asian luxury hotel groups follow some standards and certification systems. These vary between hygiene and other norms (such as HACCP and ISO) and standards related to sustainable tourism, which include Earth Check and Green Globe. Hereby Earth Check, an Australian based science and technology-benchmarking system, is applied by four hotels which includes DusitThani, Langham, Banyan and Shangri La. DusitThani is very engaged to meet the criteria of Earth Check and the overall CSR strategy is very connected to these requirements. Aman resort and Six Senses are both following the Green Globe, a similar but more recent and globally adapted standard. The reception of awards gives another indication for the implementation of CSR and sustainable activities. Again, in 2011, Banyan Tree and Six Senses are standing out by receiving many significant awards for sustainable practices such as the PATA, ASSEAN and Conde Nast awards.

\section{Discussion and Implications}

This study clearly confirms that it is important for Asian luxury hotel groups to be seen as caring for the world and implementing CSR activities similar to the findings of often research in the global hospitality industry (Holcomb et al., 2007; Bohdanowisz \& Zientara, 2008; Chung \& Parker, 2010; Levy \& Park, 2011; Sheldon \& Park, 2011). There are many similarities with these studies and it can be concluded that there is no significant difference between these Asian hotels and other leading global hotel groups. Nevertheless, some issues seem to be more relevant within this group of selected hotels. There is a lot of communication and reporting about employee relation and probably more focus on communities than reported by other studies. One reason could be a generally more people focused Asian approach. Another reason is possibly related to national rules and regulations that are generally stricter in European countries with regard to the environment. However there is no evidence in the findings that the CSR activities of sample the hotel groups follow national rules and regulations as all the standards and certificates that are noted are international. This confirms other studies that report Asian company's adaption of global standards (Welford, 2011; Cramer \& Prepscius, 2007).

From a destination management standpoint of this study explores the CSR activities and is the first attempt to identify what role sustainability and CSR activities play for their business. Findings provide the industry with an indication of the future trends and reference points with regard to CSR activities. There are two outstanding groups, Banyan Tree and Six Senses, which do not report extensively about CSR activities but also demonstrated how these activities align with their business practices and guide their actions. The fulfillment of international criteria and reception of awards supports this conclusion. Although there is no evidence of the financial performance of these groups, the expansion plans can be regarded as an indication to the positive business outlook. Therefore, it should be considered by international hotel groups that there are growing numbers of hotels who demonstrate to clients that they operate in a sustainable way. Based on the findings of most studies this will become a competitive advantage. Given that demand and supply for tourism products will continue to increase all over Asia and at the same time pressure on the resources will increase, hotels in an unspoilt environment will have a real benefit to offer to their clients. 
From a destination management standpoint the study confirms that it is important that not only the hotels but also the destination is managed in a sustainable way. Almost every hotel recognizes that they need to include other stakeholders in the sustainable practices indicated by numerous CSR activities in the category 'supply chain'. Moreover, it is be suggested that in Asian destinations best practices of some hotel groups should be taken as a guideline and vision for destination, least through leading by example.

Another interesting question that is raised from the findings is to what extend the hotels use CSR for positive public relations. The fact that CSR reports and websites cannot be easily find suggests that they are not primarily done for PR purposes. However there are regular press articles and some hotel companies, such as Banyan Tree and Six Senses, appear regularly in the press with regard to sustainable practices. Nevertheless, marketing efforts does not mean that CSR implementation is not effective and directly referred towards sustainability.

\section{Conclusion}

This study describes how the concept of sustainability and CSR has been embraced by the Asian luxury hotel industry. It confirms that CSR is a rather blurry subject and there is a lack of an overall accepted definition and guidelines. The reporting of CSR activities by the Asian luxury hotels in this research, include many activities into their CSR performances that can be regarded as their normal business practices. This makes a comparison and measurement of CSR very difficult and may also lead to a negative attitude of customers and other stakeholders who do not believe that CSR has a real sense. Moreover, it makes the excellent examples of hotels that are operated in a sustainable way less relevant and dilutes positive outcomes. The adoption of standards and certificates certainly supports a more coherent adoption and communication about CSR. However there is a multitude of standards and even within one standard, there are many different levels which make the comparisons rather complex. Nevertheless, it can be confirmed that many leading of Asian hotel companies are adopting international standards, in particular ISO, as benchmarks for their operational performances.

With regard to the motivations and outcomes of CSR activities, there is no evidence and overall results given by the hotels. However most hotel groups underline the importance of the environment and society, therefore it can be concluded that the motivations are less financial but oriented towards sustaining the basis for their operations, i.e. the natural and cultural environment including all stakeholders.

Limitations of the study include a shortage evidence of the effectiveness and outcome for the CSR activities. Furthermore, only 10 Asian international hotels chain were chosen for study, it may not be representative for all hotels in this segment.

The researchers suggest that further research should look into other hotel segments, such as local hotels or small-medium size hotel companies, in one particular country or comparing between various countries. Although there is some indication that luxury hotel groups are more concerned with sustainability and CSR issues, there is limited research of CSR in the hospitality industry which shows the alignment of the overall concepts and frameworks. Finally, it is recommended that the Asian hotel industry should improve cooperation to align social responsibility/sustainability practices and communication in order to develop awareness and understanding of CSR. At the same, this alignment can provide a better picture and make it easier for customers (tourists) and other stakeholders to understand how the hotels actively support the pressing issues of the world.

\section{References}

Albdour, A. A., \& Altarawneh, I. I. (2012). Corporate Social Responsibility and Employee Engagement in Jordan. International Journal of Business and Management, 7(16), 89-105. http://dx.doi.org/10.5539/ijbm.v7n16p89

Argandoña, A., \& Hoivik, H. (2009). Corporate Social Responsibility: One Size Does Not Fit All Collecting Evidence from Europe. Journal of Business Ethics, 89(3), 221-234. http://dx.doi.org/10.1007/s10551-010-0394-4

BanyanTree Global Foundation. (2008). Banyan Tree Global Foundation. Retrieved from http://www.banyantreeglobalfoundation.com/

Baughn, C. C., Bodie, N. L., \& McIntosh, J. C. (2007). Corporate Social and Environmental Responsibility in Asian Countries and other Geographical Regions. Corporate Social responsibility and Environmental management, 14, 189-205. http://dx.doi.org/10.1002/csr.160

Bohdanowisz, R., \& Zientara, P. (2008). Hotel companies contribution to improving the quality of life of local communities and the well-being of their employees. Tourism and Hospitality Research, 9(2), 147-158. http://dx.doi.org/10.1057/thr.2008.46

Brammer, S., \& Millington, A. (2005). Corporate Reputation and Philanthropy: An empirical Analysis. Journal 
of Business Ethics, 61, 29-44. http://dx.doi.org/10.1007/s10551-005-7443-4

Chamber, E., Chapple, W., Moon, J., \& Sullivan, M. (2003). CSR in Asia: A seven country study of CSR website reporting.

Retrieved

from http://www.nottingham.ac.uk/business/ICCSR/research.php?action=single\&id=18

Chiang, C. C. S. (2010). How corporate social responsibility influences employee job satisfaction in the hotel industry.

Retrieved

from http://digitalscholarship.unlv.edu/cgi/viewcontent.cgi?article=1599\&context=thesesdissertations

Chung, L. H., \& Parker, L. D. (2010). Managing social and environmental action and accountability in the hospitality industry: A Singapore perspective. Accounting Forum, 34, 46-53. http://dx.doi.org/10.1016/j.accfor.2009.10.003

Cramer, A., \& Prepscius, J. (2008, January 10). Corporate Social Responsibility in Asia. Global Asia, 2(3). Retrieved from http://globalasia.org/new/1.php?c=e113

Cramer, J. (2006). Corporate Social responsibility and Globalization: An Action Plan for Business. Sheffield: Greenleaf.

Drever, E. (1995). Semi-structured interview in small-scale research: A teacher's guide. Scottish Council for Research in Education. Retrieved from http://eric.ed.gov/ERICWebPortal/recordDetail?accno=ED394990

Economist. (2008). Just good business. Economist. Retrieved from http://www.economist.com.hk/node/10491077

Elkington, J. (1997). Cannibals with Forks: The Triple Bottom Line of 21st Century Business. Oxford: Capstone Publishing.

European Commission. (2011). European Policy on Corporate Social Responsibility. Brussels: European Commission. http://eur-lex.europa.eu/LexUriServ/LexUriServ.do?uri=COM:2011:0681:FIN:EN:PDF

Forsyth, P., Hoque, S., Dwyer, L., Spurr, R., Van Ho, T., \& Pambudi D. (2008). The carbon footprint of Australian tourism. Queensland, Australia: CRC for Sustainable Tourism Pty Ltd.

Franklin, D. (2008, January 17). Just good Business. The Economist. Retrieved from http://www.economist.com/node/10491077

Friedman, M. (1970). The Social Responsibility of Business is to Increase its Profits. New York Times Magazine. Retrieved from http://www.colorado.edu/studentgroups/libertarians/issues/friedman-soc-resp-business.html

Holcomb, J. L., Upchurch, R. S., \& Okumus, F. (2007). Corporate social responsibility: What are top hotel companies reporting? International Journal of Contemporary Hospitality Management, 19(6), 461-475. http://dx.doi.org/10.1108/09596110710775129

Hsieh, Y. C. (2012). Hotel companies' environmental policies and practices: A content analysis of their web pages. International Journal of Contemporary Hospitality Management, 24(1), 97-121. http://dx.doi.org/10.1108/095961112

Huimin, G., \& Ryan, C. (2011). Ethics and corporate social responsibility-An analysis of the views of Chinese hotel managers. International Journal of Hospitality Management, 30, 875-885. http://dx.doi.org/10.1016/j.ijhm.2011.01.008

Inoue, Y., \& Park, S. (2011). Effects of different dimensions of corporate social responsibility on corporate financial performance in tourism-related industries. Journal of Tourism Management, 32, 790-804. http://dx.doi.org/10.1016/j.tourman.2010.06.019

Insch, A. (2009). Green Essence or Green washing? Conceptualization and anatomy of green destination brands. 3rd International Conference on Destination Branding and Marketing, Macau: Institute for Tourism Studies.

International Organization Standardization. (2013). The International Organization for Standardization. Retrieved from http://www.iso.org/iso/home.html

Janney, J. J., \& Gove, S. (2011). Reputation and corporate Social Responsibility Aberrations, Trends and Hypocrisy: Reactions to Firm Choices in the Stock Option Backdating Scandal. Journal of Management Studies, 48(7), 1562-1585. http://dx.doi.org/10.1111/j.1467-6486.2010.00984.x

Koler, P., \& Lee, N. (2005). Corporate Social Responsibility. New Jersey: John Wiley \& Sons.

Lee, S., \& Park, S. (2009). Do socially responsible activities help hotels and casinos achieve their financial goals? $\begin{array}{lllll}\text { International Journal of Hospitality } & \text { Management, } & \text { 28, }\end{array}$ http://dx.doi.org/10.1016/j.ijhm.2008.06.003

Levy, S. E., \& Park, S. Y. (2011). An Analysis of CSR Activities in the Lodging Industry. Journal of Hospitality 
and Tourism Management, 18(1), 147-154. http://dx.doi.org/10.1375/jhtm.18.1.147

Lipman, G., DeLacy, T., Voster, S., Hawkins, R., \& Jiang, M. (Ed.). (2012). Green Growth \& Travelism: Letters from Leaders. Oxford: Goodfellow.

Luo, X., \& Bhattachara, C. B. (2006). Corporate Social Responsibility, Customer Satisfaction, and Market Value. Journal of Marketing, 70, 1-18. http://dx.doi.org/10.1509/jmkg.70.4.1

Nasdaq. (2013). Hotel and Lodging Stock Outlook-August 2012-Industry Outlook. Retrieved from http://www.nasdaq.com/article/hotel-and-lodging-stock-outlook-august-2012-industry-outlook-cm164041

Pacific Asia Travel Association. (2013). PATA: Strategic Intelligence Centre. Retrieved from http://www.pata.org/Intelligence

Peterson, D. K. (2004). Benefits of participation in corporate volunteer programs: Employees' perceptions. Personnel Review, 33(6), 615-627. http://dx.doi.org/10.1108/00483480410561510

Poon, S. (2010). Where Luxury Resorts Embrace Sustainable Development. Retrieved from http://www.amcham.com.tw/topics-archive/topics-archive-2010/vol-40-no-5/2997-

Porter, M. E., \& Kramer, M. R. (2006). Strategy and Society: The link between competitive advantage and corporate social responsibility. Harvard Business Review, 84(12), 3-17.

Senthikumar, N., Ananth, A., \& Arulraj, A. (2011). Impact of corporate social responsibility on customer satisfaction in banking service. African Journal of Business Management, 5(7), 3028-3039.

Sheldon, P. J., \& Park, S. Y. (2011). An exploratory study of corporate social responsibility in the U.S. travel industry. Journal of Travel Research, 50(4), 392-407. http://dx.doi.org/10.1177/0047287510371230

Simpson, M. C., Gössling, S., Scott, D., Hall, C. M., \& Gladin, E. (2008). Climate change adaptation and mitigation in the tourism sector: Frameworks, tools and practices. Retrieved from http://sdt.unwto.org/sites/all/files/docpdf/ccoxford.pdf

Tanimoto, K., \& Suzuki, K. (2005). Corporate Social Responsibility in Japan: Analyzing the participation companies in global reporting initiative. EIJS (Stockholm School of Economics) working paper series, (208).

The Brand Company. (2012). Asian Hospitality Brand Survey 2012: Summary of Result. Retrieved from http://www.thebrandco.com/the-fount-of wisdom/FINAL_TBC_Research_2011_05_18_V6.pdf

Tsai, H., Tsang, N. K., \& Cheng, S. K. (2012). Hotel employees' perceptions on corporate social responsibility: The case of Hong Kong. International Journal of Hospitality Management, 31(4), 1143-1154. http://dx.doi.org/10.1016/j.ijhm.2012.02.002

Veal, A. J. (2011). Research methods for leisure \& tourism: A practical guide (4th ed.). England: Prentice Hall.

Weber, R. P. (1985). Basic Content Analysis. Newbury Park, VC: SAGE.

Welford, R. (2005). Corporate Social Responsibility in Europe, North America and Asia. Journal of Corporate Citizenship, 2005(17), 33-52.

Welford, R. (2011). The Future of CSR: CSR Asia's CSR in 10 Project. Retrieved from http://www.csr-asia.com/report/report_CSRin10_2011.pdf

White, A. L. (2008). Culture Matters: The Soul of CSR in Emerging Economics. Retrieved fromhttps://www.bsr.org/reports/CultureMatters_CSRSpirituality_1.pdf

Williams, C. A., \& Aguilera, R. V. (2008). Corporate social responsibility in a comparative perspective. Oxford handbook of corporate social responsibility, 452-472.

World Business Council for Sustainable Development. (2010). WBCSD: Business solutions for sustainability world. Retrieved from http://www.wbcsd.org/web/development.htm

World Tourism Organization. (2011). UNWTO: Tourism Highlights 2012 Edition. Retrieved from http://dtxtq4w60xqpw.cloudfront.net/sites/all/files/docpdf/unwtohighlights12enhr_1.pdf

World Tourism Organization. (n. d.). UNWTO: Member states. Retrieved from http://www2.unwto.org/en/members/states

\section{Copyrights}

Copyright for this article is retained by the author(s), with first publication rights granted to the journal.

This is an open-access article distributed under the terms and conditions of the Creative Commons Attribution license (http://creativecommons.org/licenses/by/3.0/). 